\title{
Changing of some parameters of the soil-plant system as an effect of different composts
}

\section{Anita Szabó - Emese Berta-Szabó - Péter Tamás Nagy - Andrea Balla Kovács - Imre Vágó}

Department of Agricultural Chemistry and Soil Science, Faculty of Agricultural and Food Sciences and Environmental Management, University of Debrecen,

no. 138. Böszörményi St., 4032 Debrecen, Hungary

szaboanita@agr.unideb.hu

Keywords:, compost mixing ratio, sustainable plant production

\section{SUMMARY}

Composting is an alternative way for practicing site-specific and environmental friendly plant nutrient supply. Our aim was to study the effect of different composts on plant and soil system.

Pot experiment with acidic sandy soil blended with three composts in five $(0 \%, 5 \%, 10 \%, 25 \%$ and $50 \%)$ proportion was set up. Our experimental plant was perennial ryegrass (Lolium perenne L.). After the harvest of ryegrass we measured the fresh and dry weight of harvested plants, the $\mathrm{P}-, \mathrm{K}-, \mathrm{Mg}$-contents, and the $\mathrm{pH}$ of soils.

The three composts had different effect on dry weight production and on nutrient-supply of soil. We established that one of the compost had significantly larger effect on the dry weight of ryegrass compared to the others. In this study we proved that favourable compost/soil proportion is different in the case of different composts.

\section{INTRODUCTION}

The location of waste emitted in increasing volume is one of the most important environmental problems of sustainable development. The disposal of by-products and waste materials formed in the public spaces of cities and during the processing of agricultural row material in a landfill is inconceivable, so we have to recycle them (Simándi, 2008).

One of the solutions for this problem is composting. Beyond this the fertilization of horticultural crops with the composted waste materials, containing a large amount of organic matter content, is one of the alternative, environmental friendly plant nutrient supply practices.

Scientific research on the positive effect of compost on soil parameters and yield has been published widely both in Hungarian and international literature (Gigliotti et al., 1966, Kádár-Morvai, 2007, Keserü, 2007).

The reason of that we chose the more accurate cognition of compost utilization is to do more effective and site-specific the nutrient supply with composts. Our aim was to study and evaluate the relations between the dry matter productions of plant, the compost:soil ration and the nutrient content of soil.

\section{MATERIALS AND METHODS}

Compost utilization experiment with 3 different composts under controlled conditions was set up in the glasshouse of the Department of Agricultural Chemistry and Soil Science. Our aim was to study the effect of different composts on plant and soil system.

We received the 3 composts from one of the partners of University of Debrecen in 2009. The composition and the production method of them is confidential. Composts were sieved $(<2 \mathrm{~mm})$, because degradation of the large particles in the pots is slow.

Composts were mixed with acidic sandy soil in four proportions $(5 \%, 10 \%, 25 \%$ and $50 \%)$, in four repetition (Table 1). After the volumetric mixture we set up the pots randomised.

Table 1

The compost-soil ratio of treatments

\begin{tabular}{|c|c|c|}
\hline \multicolumn{3}{|c|}{ The compost-soil ratio of treatments } \\
\hline \multirow{2}{*}{ Treatments } & Compost $(\%)$ & Sandy soil (\%) \\
\hline 1. & 0 & 100 \\
\hline 2. & 5 & 95 \\
\hline 3. & 10 & 90 \\
\hline 4. & 25 & 75 \\
\hline 5. & 50 & 50 \\
\hline
\end{tabular}

After one week maturation of compost-soil mixture we sowed perennial ryegrass (Lolium perenne L.). The advantage of ryegrass is that it grows quite fast, tolerates the glasshouse conditions well and it indicates the 
effect of treatments well. After the shooting of ryegrass the water supply of the $2.5 \mathrm{~kg}$ pots was carried out at 60 per cent of field water capacity of soil. In our department previous researches confirmed that irrigation at 60 per cent of field water capacity is optimal in sandy soils (Loch et al., 1992).

After the harvest we measured the fresh- and dry mass of ryegrass. We investigated the $0.01 \mathrm{M} \mathrm{CaCl}_{2}$ extractable $\mathrm{P}-, \mathrm{K}-, \mathrm{Mg}$-content and the $\mathrm{pH}$ values of dried and sieved soils.

\section{Chemical analysis:}

\section{a.) $0.01 \mathrm{M} \mathrm{CaCl}_{2}$-soil extraction method}

The P-, K-, Mg-contents of the soils were measured in $0.01 \mathrm{M} \mathrm{CaCl}_{2}$ extractant (Houba et al., 1990) with UNICAM SP95B AAS and SKALAR Continuous Flow Analyzer at the laboratory of the Department of Agricultural Chemistry and Soil Science. We measured the $\mathrm{pH}$ of the soils after $0.01 \mathrm{M} \mathrm{CaCl}_{2}$ extraction.

\section{b.) Statistical analyses}

We used variance analyses for the processing of the data. All statistical analyses were performed with a Microsoft Excel Macro (Tolner, 2008; Vágó, 2008) according to Sváb (1981). With this program we determined the significance level of the treatment effect and significant difference in $\mathrm{P}=5 \%$ (LSD5\%).

\section{RESULTS AND DISCUSSION}

The fresh- and dry weights of ryegrass in each treatments (5 compost: soil rate; 3 compost) are shown in Figure 1 and Figure 2.

\section{Figure 1: Fresh weight production of ryegrass in each treatment $\left(\mathrm{g} \mathrm{pot}^{-1}\right)$}

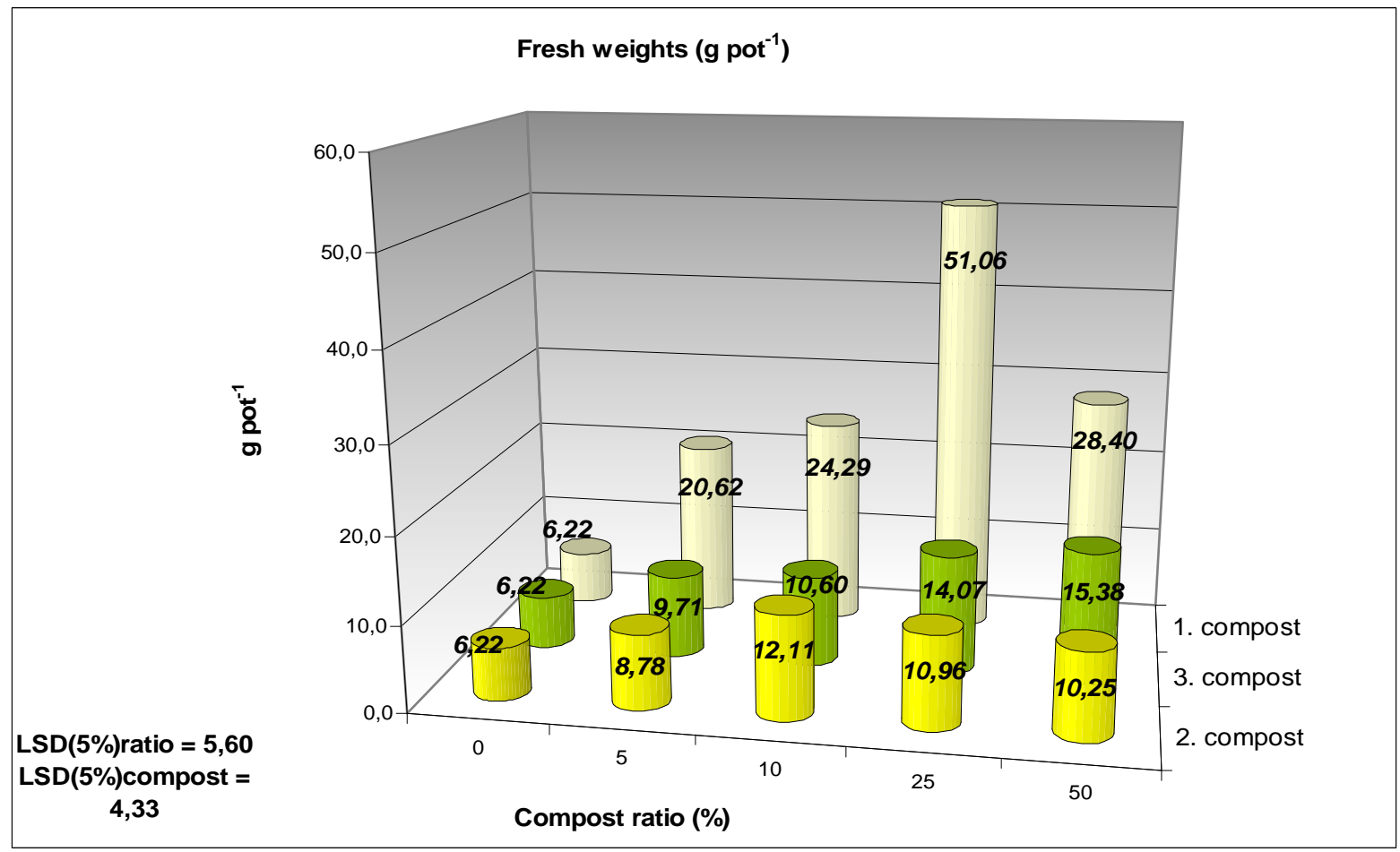

As it is represented in Figure 1 and Figure 2 the compost:soil ratio and the different composts had a significant effect $(\mathrm{P}=0.1 \%)$ on the fresh and dry weight of ryegrass.

We found the highest positive effect in the case of 1 st compost. If a $25 \%$ compost dose were applied, the fresh weight increasing effect of 1 st compost would reach a value of $45 \mathrm{~g} \mathrm{pot}^{-1}$. The increasing dose of compost didn't caused higher yields. It can be stated that the optimal compost:soil ratio is $25: 75 \%$. The 25 and $50 \%$ dose of 3rd compost increased significantly the yield. The yield increasing effect of $50 \%$ compost was nearly $10 \mathrm{~g}$ $\operatorname{pot}^{-1}$. The 2 nd compost had a moderate effect, but the $10 \%$ compost dose increased significantly the dry and fresh weight of ryegrass. As the data show the recommended compost doses are different for each compost. 
Figure 2: Dry weight production of ryegrass in each treatment $\left(\mathrm{g} \mathrm{pot}^{-1}\right)$

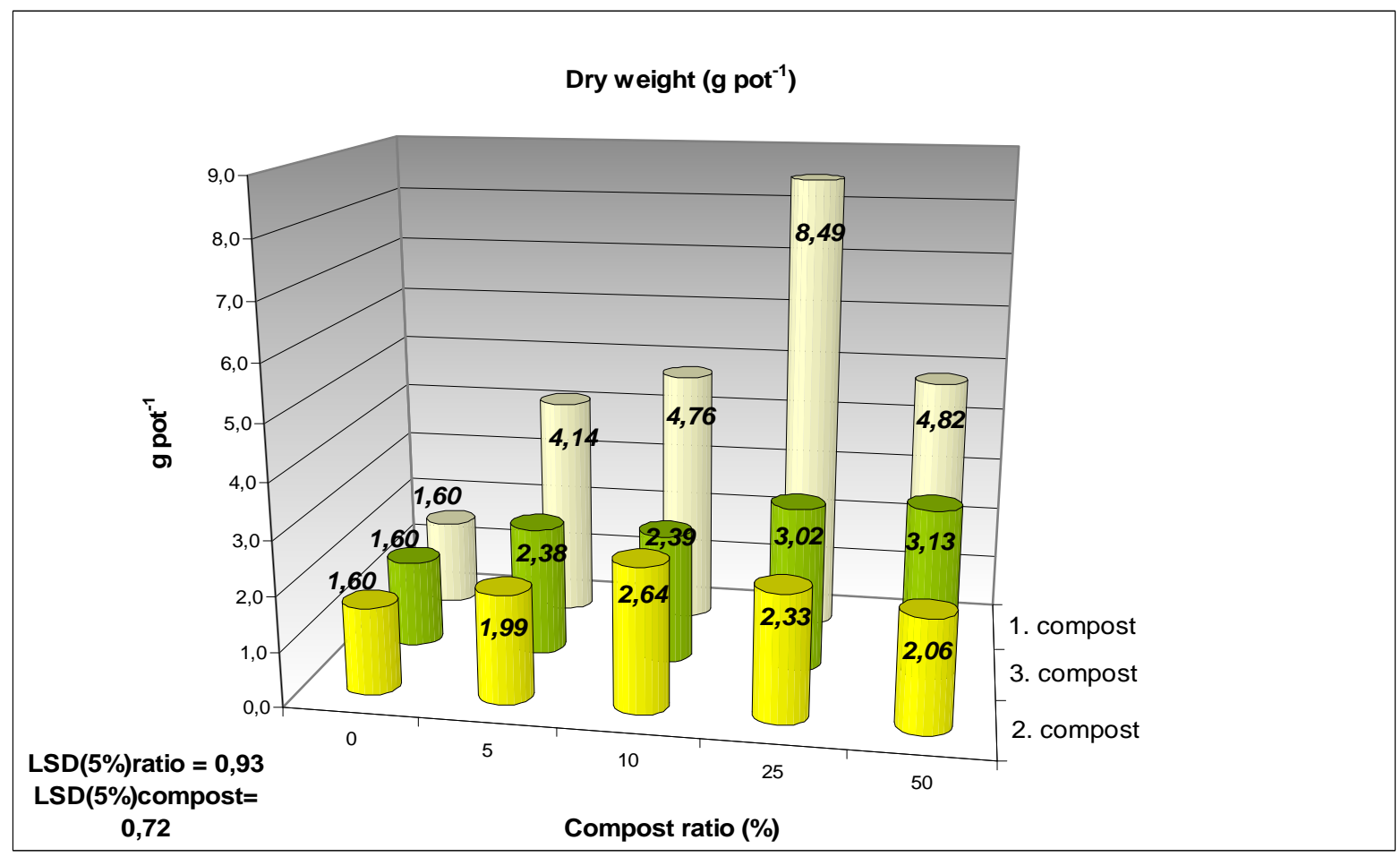

Figure 3: The 0.01 $\mathrm{M} \mathrm{CaCl}_{2}$ extractable $\mathbf{P}$ content of soil

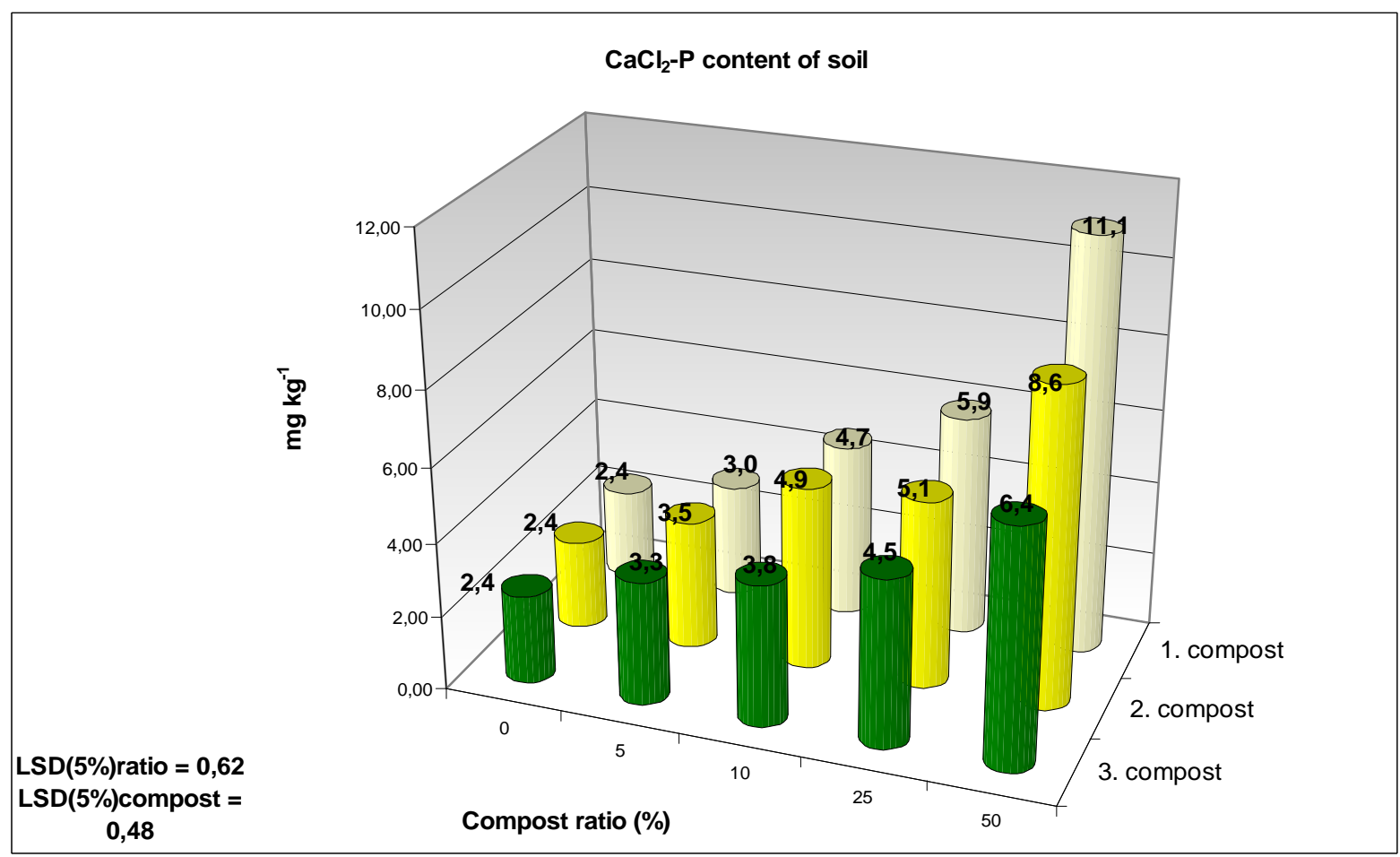

The P-, $\mathrm{K}-, \mathrm{Mg}$ content of the soil determined in $0.01 \mathrm{M} \mathrm{CaCl}_{2}$ are represented in Figure 3, 4, 5. The compost:soil ratio modified significantly $(\mathrm{P}=0.1 \%)$ the $\mathrm{CaCl}_{2}$ extractable nutrient content.

All studied compost increased significantly the amount of $\mathrm{CaCl}_{2}-\mathrm{P}$ (Figure 3). The applying of $50 \%$ compost increased the P content of soil by 2-4 times higher. We found the highest easily available P concentration (11 $\mathrm{mg} \mathrm{kg}^{-1}$ ) in case of 1 st compost. A moderate effect was observable with the $2 \mathrm{nd}$ and $3 \mathrm{rd}$ compost. 
Figure 4: The $0.01 \mathbf{M ~ C a C l}_{2}$ extractable $\mathrm{K}$ content of soil

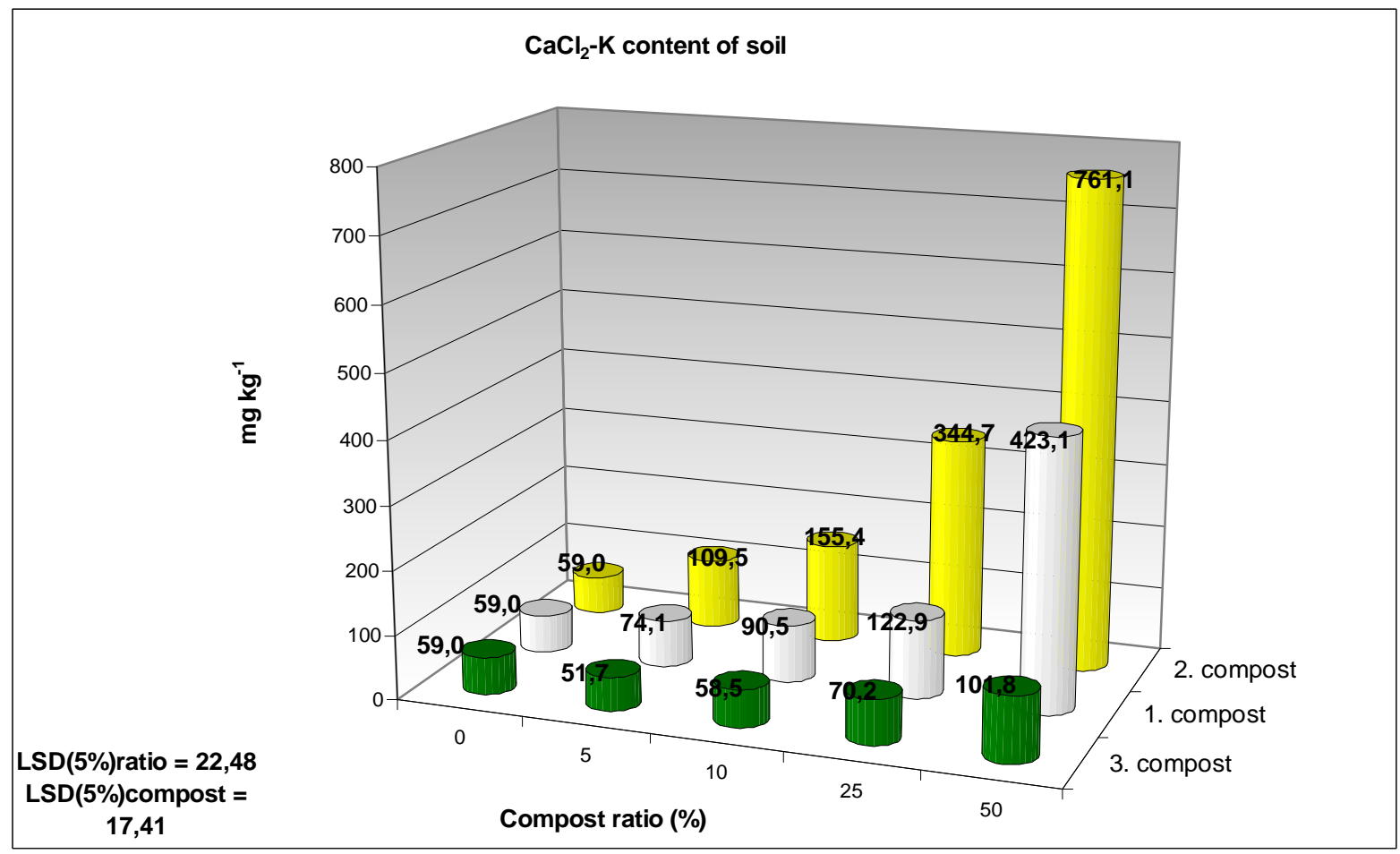

Figure 5: The $0.01 \mathrm{M} \mathrm{CaCl}_{2}$ extractable $\mathrm{Mg}$ content of soil

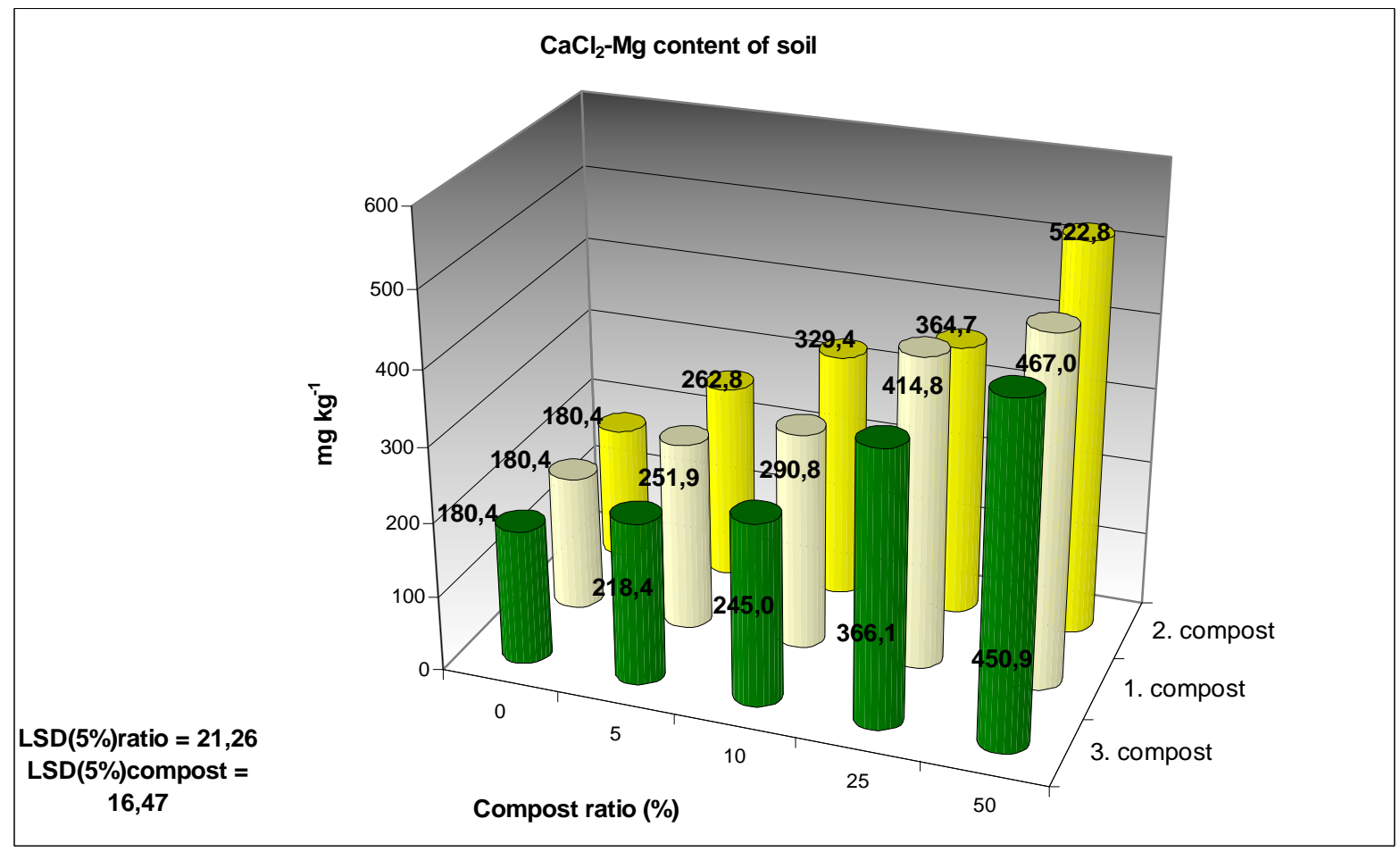

As it is represented in Figure 4 and Figure 5 the increasing compost rates caused the increasing of $\mathrm{K}, \mathrm{Mg}$ content of soil. The $\mathrm{CaCl}_{2}-\mathrm{K}$ and $-\mathrm{Mg}$ content of the 2 nd compost was higher than that of other composts. We found the lowest nutrient content in case of 3 rd compost. 
The $\mathrm{pH}$ values of the soils determined in $\mathrm{CaCl}_{2}$ extracts are shown in Figure 6. The treatments increased significantly the $\mathrm{pH}$ values of soils $(\mathrm{P}=0.1 \%)$. The 2 nd compost had the highest effect on the $\mathrm{pH}$. All ratios caused significant increase. If a $50 \%$ compost dose were applied the $\mathrm{pH}$ would be in neutral range $(\mathrm{pH}=6.81)$. In case of 1 st and 3 rd composts the 25 and $50 \%$ dose caused significant increase.

\section{Figure 6: $\mathbf{p H}_{(\mathrm{CaCl2})}$ of soil}

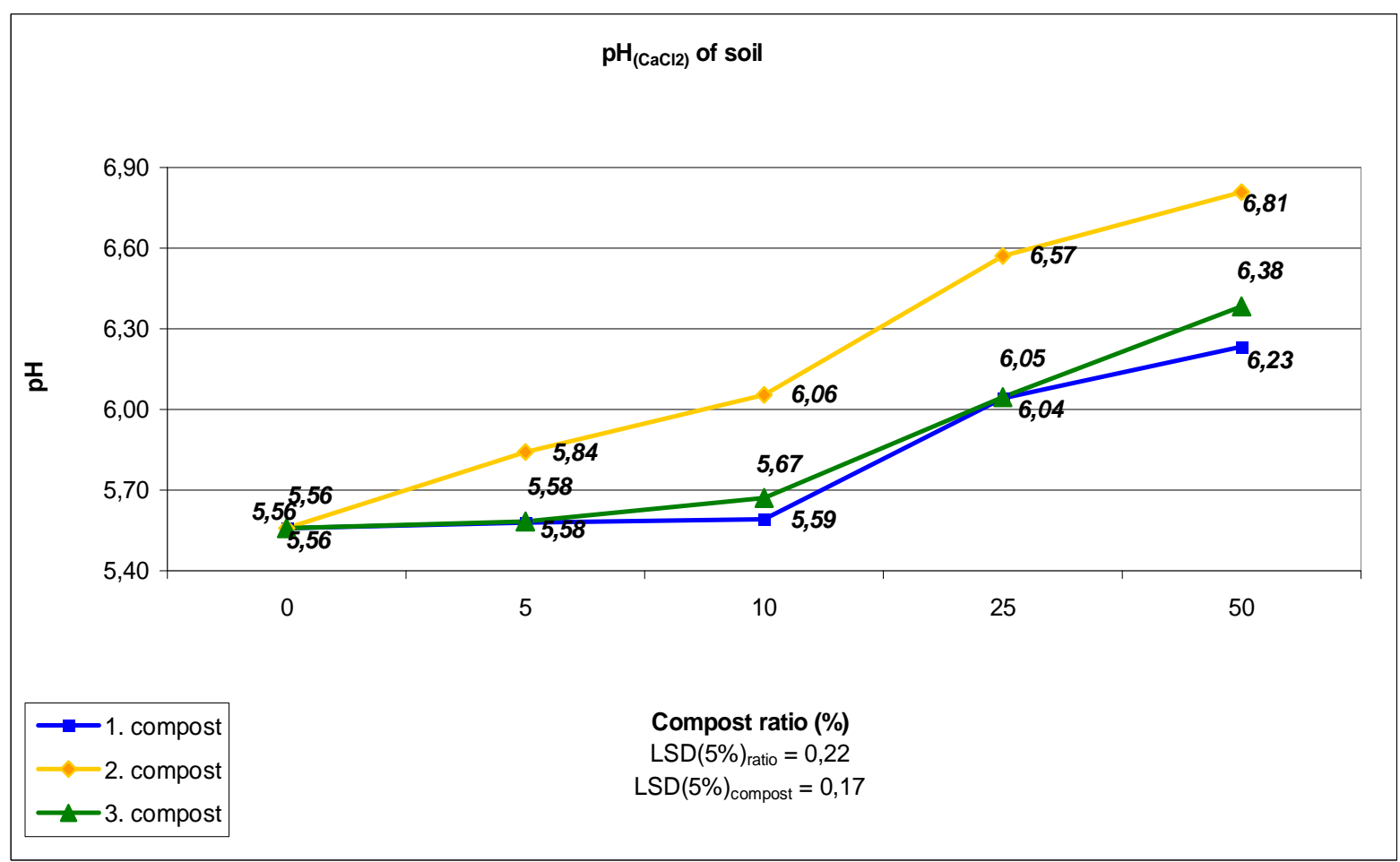

\section{CONCLUSIONS}

From the results of the study it was concluded as follows:

- However the nutrient content and $\mathrm{pH}$ of soils increased significantly as an effect of increasing compost doses, the optimal compost doses in respect of fresh and dry weight production were different in case of each compost.

- The 1st compost affected the highest increase in the amount of yield, and the optimal compost:soil rate was $25: 75 \%$.

- The optimal dose of 3 rd compost was the $50 \%$ rate. The 2 nd compost had a moderate effect, but the $10 \%$ compost dose increased significantly the dry and fresh weight of ryegrass.

\section{REFERENCES}

Gigliotti, G., Businelli, D. \& Giusquiani, P.L. (1966): Trace metal uptake and distribution in corn plants grown on a 6-year urban waste compost amended soil. Agric. Ecosyst. and Environm. 58. 199-206.

Houba, V.J.G. - Novozamsky, L. - Lexmond, T.M. - Van der Lee, J.J. (1990): Applicability of 0,01 $\mathrm{M} \mathrm{CaCl}_{2}$ as a single extraction solution for the assessment of the nutrient status of soils and other diagnostic purposes. Commun. Soil Sci. Plant Anal. 21. 2281-2290. p.

Kádár, I. - Morvai, B. (2007): Ipari-kommunális szennyvíziszap-terhelés hatásának vizsgálata tenyészedény-kísérletben. AGROKÉMIA ÉS TALAJTAN 56 (2007) 2

Keserü, Zs. (2007): A szennyvíziszap-komposzt erdészeti hasznosíthatóságának kérdései. Erdészeti, Környezettudományi, Természetvédelmi és Vadgazdálkodási Tudományos Konferencia (EKTV-TK) konferencia 2007. december 11. Sopron.

Loch, J. - Kiss Sz. - Vágó I. (1992): A kálium-, kalcium-, magnézium- és vízellátás hatása az őszi búza szemtermésére és magnéziumfelvételére. 4. Magyar Magnézium Szimpózium, Balatonszéplak. In: Magnesium Research 5. Abstr. 238.

Simándi, P. (2008): Különböző szerves hulladékok és kezelésük után keletkezett termékek kémiai vizsgálata. Értekezés, Debrecen. 8 p.

Sváb, J. (1981): Biometriai módszerek a kutatásban. Mezőgazdasági Kiadó, Budapest

Tolner, L. - Vágó, I. - Czinkota, I. - Rékási, M. - Kovács, Z. (2008): Field testing of a new, more efficient liming method. Cereal Research Communications. 36. 543 - 546. p.

Vágó, I. - Tolner, L. - Eichler-Löbermann, B. - Czinkota, I. - Kovács, B. (2008): Long-term effects of liming on the dry matter production and chemical composition of perennial ryegrass (Lolium perenne L.). Cereal Research Communications. 36.103 - 106. p. 